\title{
A brief introduction to London's underground railways and land use
}

\author{
Nathan Darroch ${ }^{\mathrm{a}}$ \\ London Underground
}

\begin{abstract}
The most common perception of London's underground railways and land use is that the railway stimulated suburban development and growth of the city. However, the interface between the railway, private property interests, and urban and suburban development is much more complicated than this. This paper introduces a brief overview of the interrelationship between the railway and land use in the central zone of London and some of the complexities involved with the presence of the railway and the development or use of adjoining lands. As this topic appears to be little discussed, evidence is used from London Underground records and specialist knowledge to form the argument that the topic should have greater discussion academically and practically.
\end{abstract}

\section{Introduction}

When the world's first underground railway, the Metropoli$\tan$ Railway, was opened in 1863, it was less than forty years after the opening of the world's first public railway to use a steam locomotive to haul a passenger train between two urban centers (the Stockton and Darlington Railway, 1825). By the time of the Metropolitan Railway, main line railways, using the initial principles of the Stockton \& Darlington Railway and the Liverpool and Manchester Railway (1830), had already arrived in London, causing much demolition of property and the conversion of land from residential and commercial use to railway specific purposes (Dyos, 1955; Kellett, 1993). The effects of these railways on the city is apparent today by the loss of developable areas, thus creating swathes of land and air space, which can have no other purpose than for limited use as small industrial units, mostly in railway arches. The decline in the requirement for engine sheds, sidings, carriage-stabling facilities, and goods sheds has resulted in the reclaiming of railway land for commercial and residential development where once the land was put to solely railway purposes.

The benefits of an underground railway are apparent when general consideration is given to them. While there is much discussion on the issue of transport systems on urban development, especially main line railways (Levinson, 2008; Kellett, 1969), there appears to be little discussion of the interrelationship between London's underground railways and how land use, property rights and interests, have had an effect and continue to affect one another. This paper therefore introduces some of the key aspects relating to the underground railways, considering how land use and property interests initially affected the location of the railways, and how the presence of the railway now affects the development and use of land.

To cover the different aspects of the railway and its relationship to land use and urban design fully would require a whole series of papers, constituting many volumes. Each aspect has its own difficulty in presence, design, and ability to be incorporated within the urban realm. For the purposes of this paper concentration is specifically given to the central zone, extending outwards to key locations of interest, to demonstrate some of the issues involved. Its purpose is to demonstrate that the transport and land use researcher, engineer, surveyor, and historian must look beyond what obvious effects the underground railway has had on land use and consider how the railway and land use affect each other, why, and how they will do so in future.

\subsection{A note on use of terms}

Whereas the phrase 'the tube' is commonly used in reference to the whole of London's' underground railway network, its use is inaccurate. The 'tubes' are the deep level bored tunnels constructed using a tunnelling shield or tunnel boring machines, such as the Northern and Victoria lines. The earlier lines, such as the Metropolitan and Circle, on the other hand, were constructed using traditional mining methods and by the cut and cover technique, and are referred to as the sub-surface railways. This paper therefore uses the term 'underground' to encapsulate the whole of London's underground railway. Where the term 'the tube' or 'tube' is used, it is in its correct form to describe a deep tube tunnel.

a nathan.darroch@tube.tfl.gov.uk 


\subsection{Historical overview}

The Metropolitan Railway was first speculated in the early 1850s, to run from Paddington, a residential suburb and the location of a main line railway terminus to Farringdon, near the financial center of the British Empire. Its purpose was to tap into existing traffic flows heavily served by omnibuses, and to compete for the traffic that these omnibus services had developed (Jackson, 1986, p.18). Upon opening, it was instantly popular and stimulated government proposals for a circular railway around the central zone of the metropolis. This latter railway took twenty years to complete and forms today's Circle line. Outside of this railway, branches from the Metropolitan and Circle lines extended outwards into the suburbs, further stimulating housing development and commuter traffic.

The popular but limited benefit the early sub-surface railways gave to the central areas of London caused the speculation of tube railways, all of which were planned to pass through the city center and thus provide easier access to the west end and the City from the suburbs, such as Stockwell, Kensington, Finsbury Park, Shepherds Bush, and Paddington. By 1907, the cores of these routes were complete and running fast, frequent services. Eventually, they were extended further out into the suburbs, in tunnel and on the surface, as had the earlier subsurface railways.

With the capacity problems on the existing London transport networks, electrification of former steam-operated main line railways was undertaken along with the proposal for a new tube railway to run from the northeast corner of the city (Walthamstow) to Brixton via the central zone. This opened in sections from the late 1960s to the early 1970s as the Victoria line, not only was it the first automated railway in the world, but it was also the first of the underground railways entitled to take the sub-soil and lands it required with only the payment of compensation (British Transport Commission Act 1955). All of the earlier railways had had to buy either property or easements. The Brixton extension was also the first to introduce a 'protective sleeve' around the tunnel to help ensure that the railway would not be affected by development of land above it (London Transport Act 1966), a feature prevalent on the Jubilee line extension, opened in 1999 (Darroch, 2012).

\section{The sub-surface railways and land use}

Perhaps one of the key discussion points of the development of the sub-surface railways, especially the Metropolitan Railway, was the disruption caused to property and traffic along its line of route during construction. However, there are additional issues regarding the interrelationship between the subsurface railways, private property, and land use. The following are some of the key points.

\subsection{The railway under the public highway}

The railway had little long-term effect on land use and property adjacent to its alignment between Kings Cross and Paddington. This is due to its being limited, to some degree, to being away from private property and located under public highway (Kellett, 1969, p.50), fig. 1. What is required, however, is for property developers and landowners to take into account the effect any re-development of their property will impose on the presence of the railway. For example, if one of the adjoining buildings were to be demolished, the developers' engineers would need to take into account ground movement, and manage the construction to ensure the support of the railway tunnel.

\subsection{Tunnelling under property}

Though the railway was predominantly under the public highway, there were locations where the railway was required to pass under, or purchase and demolish privately owned, already developed land. Great Portland Street and Edgware Road Stations are such examples. This brings us to the requirement for the railway company to accommodate land and property. At Great Portland Street, the railway was still predominantly located under the road; though its western end was tunnelled under property, in 'The Crescent' (figs. 2 and 3). Whereas the railway company would have had to undertake works to ensure support for the existing buildings, the presence of the railway over the long-term potentially limits what can be done to the properties without possible substantial, expensive works to ensure that the railways assets are not adversely affected. As such, the property owner will need to determine how much money they are willing to pay for the re-development of their property and what financial return they could gain from it, especially as they would be potentially limited to what they could do, from a town planning and design perspective anyway.

\subsection{Limiting development}

A substantial effect of the presence of the Metropolitan Railway in the east is its presence limiting development. When the Metropolitan Railway was under construction between Kings Cross and Farringdon demolition of property had already been undertaken, for the construction of Farringdon Road in the early 1850s (Jackson, 1986, p.19). The railway therefore had very little short-term effect on property in this area. However, it does have a long-term effect by reducing the developable land, a factor also pertinent to the construction 


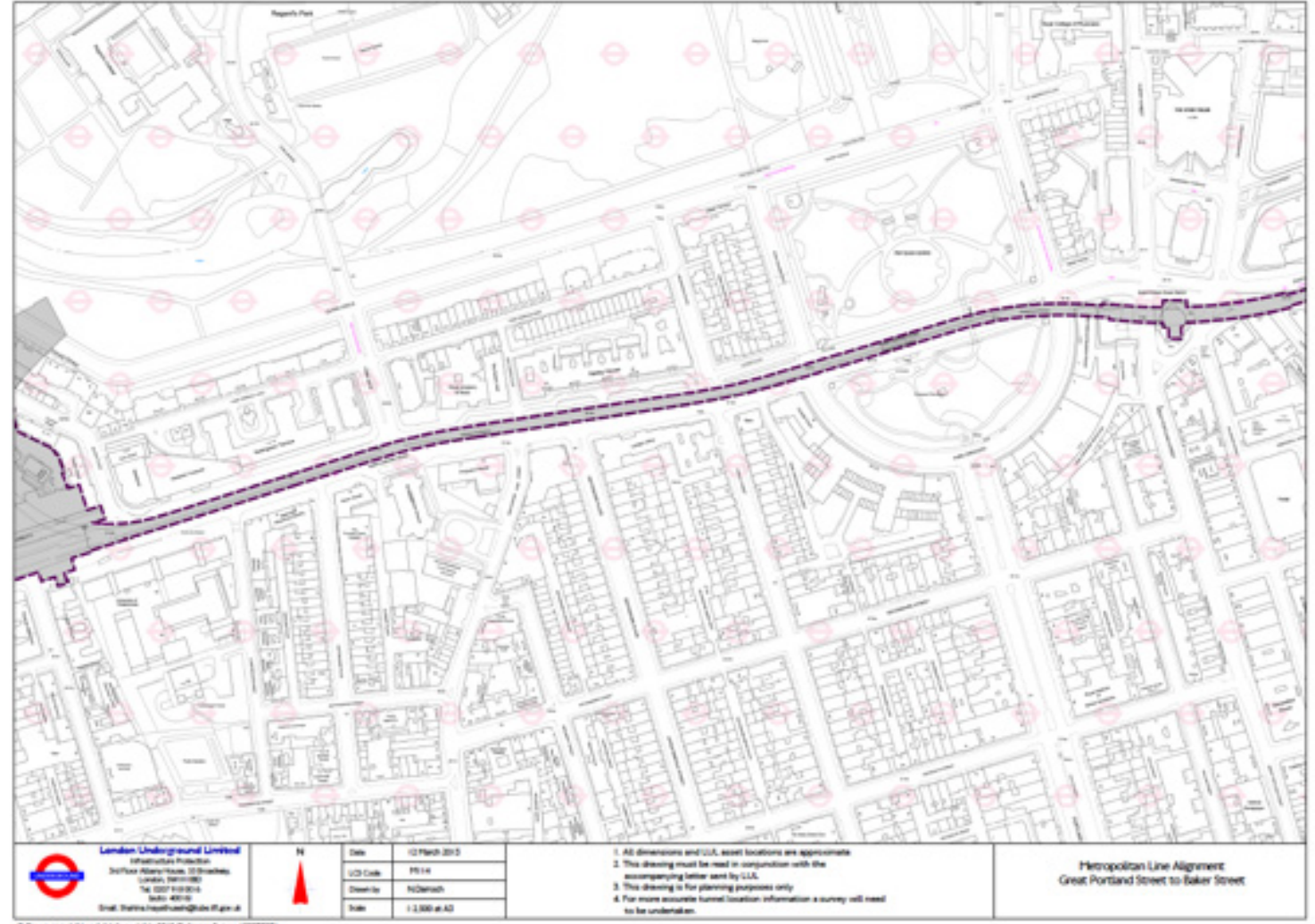

Figure 1: A 1:5000 at A3 plan, showing the alignment of the Metropolitan line (outlined dashed red and shaded gray) between Great Portland Street and Baker Street Stations, overlaid on 2013 OS mapping. Note how the railway is located solely under the public highway.

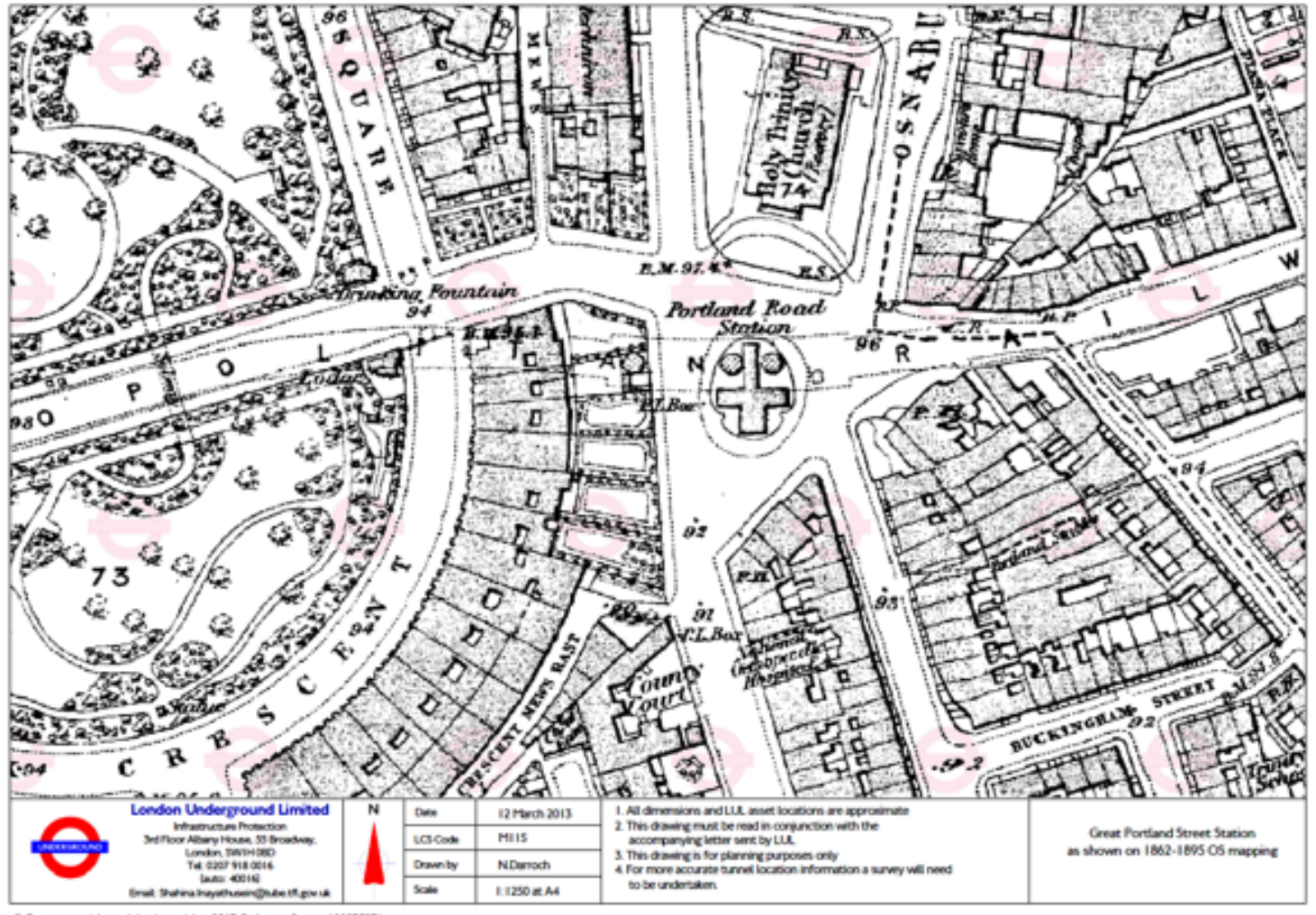

Figure 2: A 1:1250 at A4 plan, showing Great Portland Street Station on 1862-1895 OS mapping, note, how the railway tunnels pass under the buildings to the west of Great Portland Street Station. 


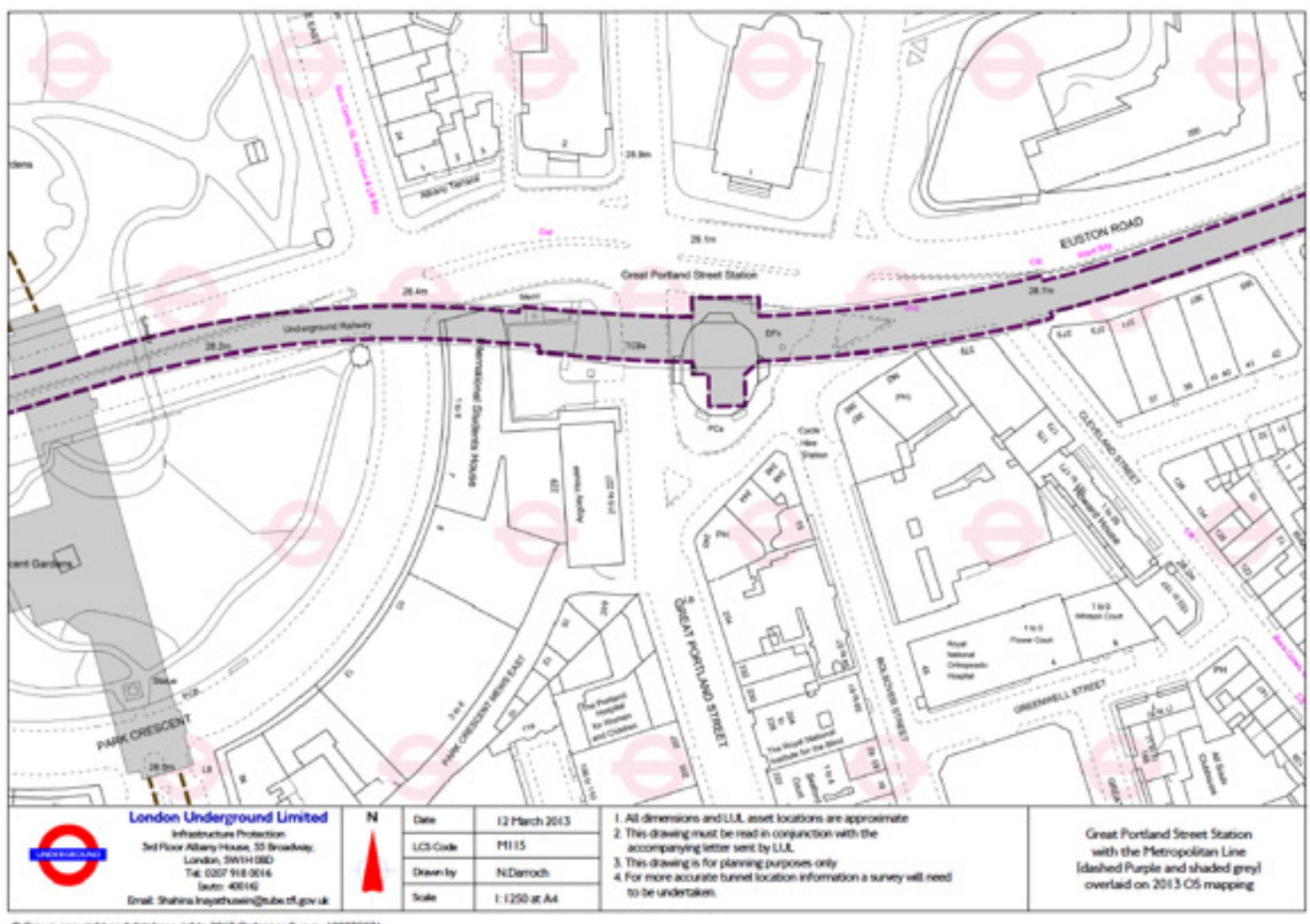

Figure 3: A 1:1250 at A4 plan, showing Great Portland Street Station on 2013 OS mapping, note, how the railway tunnels pass under the buildings to the west of Great Portland Street Station.

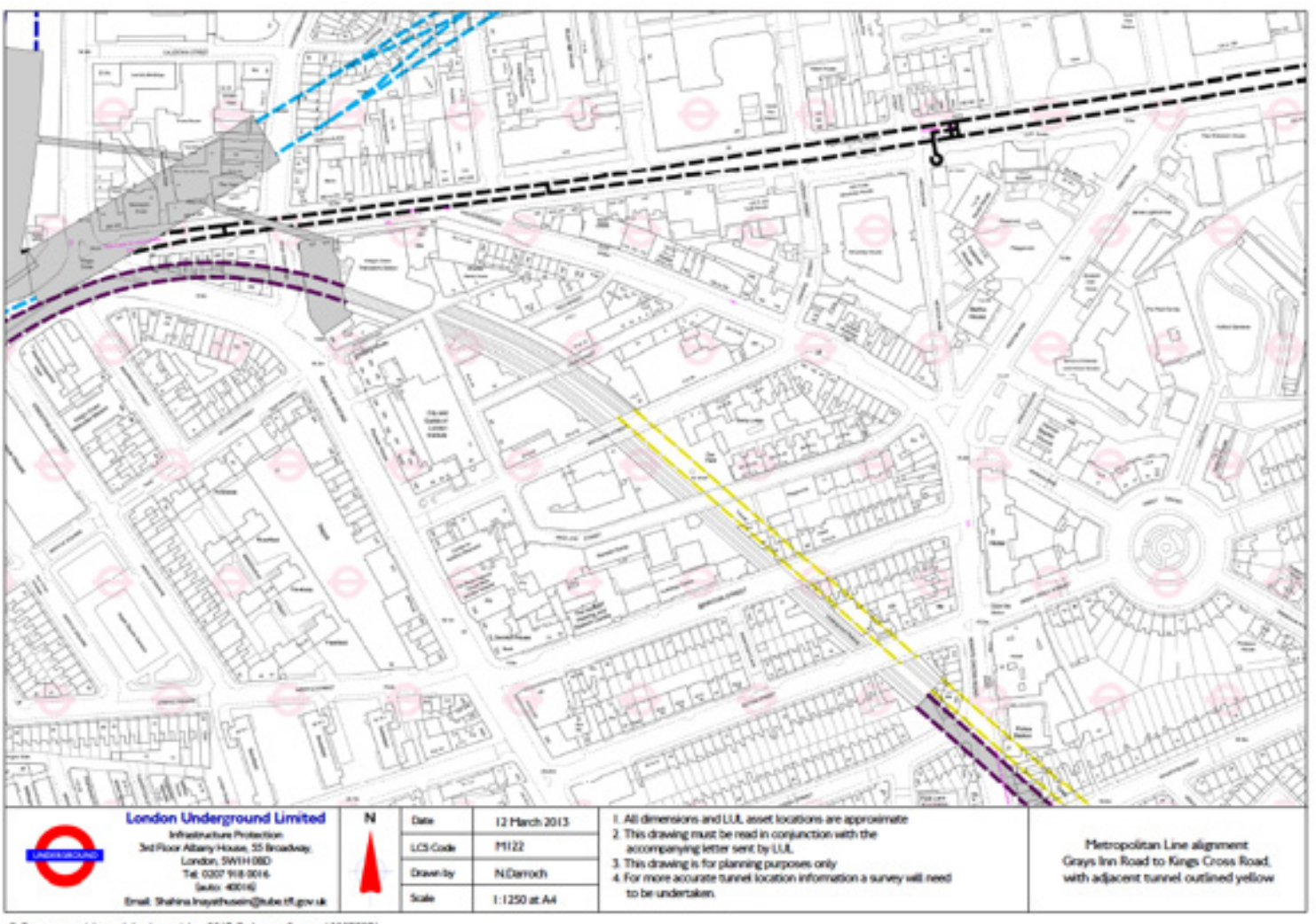

Figure 4: 1:1250 at A4 plan, showing the alignment of the Metropolitan line, between Grays Inn Road and Kings Cross Road, on 2013 OS mapping. Also shown is the alignment of the adjacent brick-arch Network Rail tunnel (dashed yellow). The blue and black lines are the alignments of the deep tube tunnels for the Victoria and Northern lines respectively. 
of the Circle line in the west, between Paddington and South Kensington, though in instances on the latter section this has been overcome. Between Gray's Inn Road and Kings Cross Road, the railway is located in deep cutting (fig. 4). Due to the proximity of a brick railway tunnel, parallel to the railway cutting, and adjoining properties constructed above the cutting retaining walls and the tunnel, the bridging over of the railway is difficult and has thus resulted in a swathe of land, which can only be used for the purposes of the railway. This will continue to be the case unless a developer is willing to purchase the adjacent properties and design an engineering solution, which will not impose load on any of the existing railway structures.

\subsection{Developing above the railway}

Whereas the last point suggests that there are difficulties in developing above the railway, there is an alternative possibility for future development. This is the bridging over of the railway and the locating of buildings in the air space above the railway. When the Metropolitan District Railway Company, opened its St James's Park Station in 1868, the station was in an open cutting with a substantial glass roof (fig. 5). Today, however, the station is barely noticeable due to its inclusion within an office development, located above it (fig. 6). This was facilitated by the spanning of the railway by a raft supported on piles, which does not transfer load from the development on to the railway retaining walls, constructed between 1927 and 1931. Whereas the owners of the underground railways (the Underground Electric Railways Company of London) undertook this work, it has set a precedent that has been copied over several places in the central area of London, such as Gloucester Road station (fig. 7), where a retail development is located above the originally uncovered station. Not only does such development minimize loss of land for uses other than for the railway, it also gains the railway an additional income, other than fares, that can be used to continue the upgrading of the railway network.

\subsection{The sub-surface railways and land use}

What these brief points show, is that though the sub-surface railways are located underground in the central area of the city, whether in tunnel or cutting, they still have an effect on land use, and that land use also has an effect on the railway. Whereas this is very clearly a physical effect, there are also theoretical effects in the relationship as well, though these are more clearly discerned by considering the presence of the deep tube railways in the sub-soil, which also have a physical effect on property development.

\section{The deep tube railways and land use}

When the early tube railways were promoted and constructed between 1885 and 1907, their principle alignment was under the public highway, in much the same way that the majority of the Metropolitan Railway, between Kings Cross and Paddington and the extension to Finchley Road, had been. As with the Metropolitan Railway, this was due to the financial savings by not tunnelling under property, the land under the public highway considered as worthless to the adjoining landowners (Joint Select Committee 1892, p.25). The main cost in this period was therefore the construction of the railway and the purchase of property for stations. There were, however, locations where the railways had to pass under property, one example being where the City \& South London Railway passed under warehouses adjacent to the River Thames costing the company, $£ 3,000$ for an easement of fifty to sixty yards (Joint Select Committee 1892, p.19). The granting of this easement, however, did not grant the railway company any powers for the protection of its assets; it was only the right to the sub-soil through which its tunnel and trains were to pass. With the extensions of the tubes from 1913 until the 1940s, the railways began passing under property, but as with the City \& South London, this was subject to the purchase of easements, which could considerably drive up costs of delivering the new railway.

\subsection{Initial minimal effect on property}

During this time, the presence of the railways under property, as long as they were a substantial depth below, had minimal effect on the development of land, due to the low-rise nature and shallow foundations of buildings at that time. However, once structures that are more substantial started to be constructed, from the 1950s, the presence of a tube railway or a related asset, such as an escalator shaft started to be problematic (Fig. 8). 


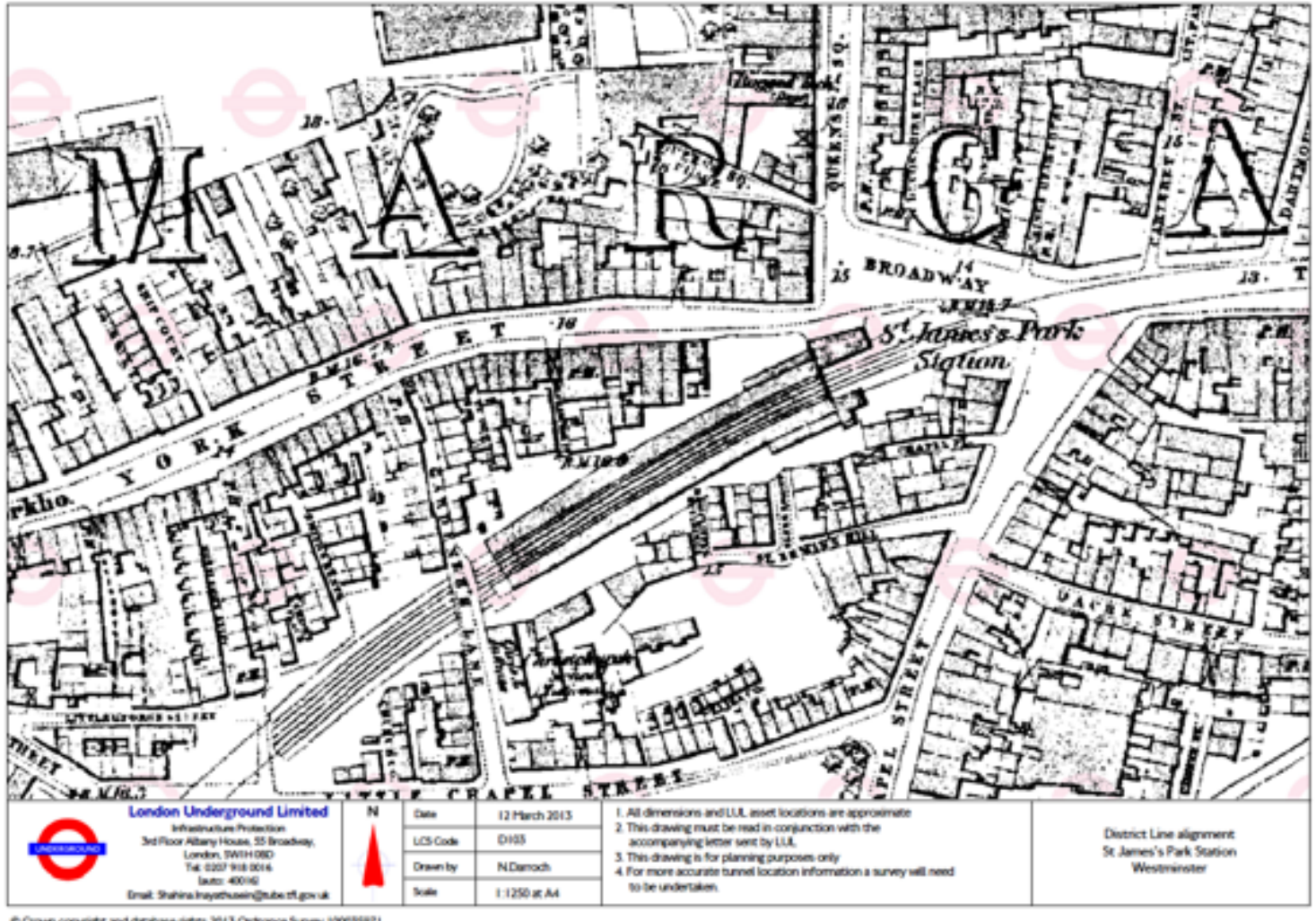

Figure 5: 1:1250 at A4 plan, showing St James's Park Station, with the District and Circle lines as show on 1862-1895 OS mapping. Note the large area of densely developed central London that has been put over to railway use, despite the underground minimizing its effect on land use.

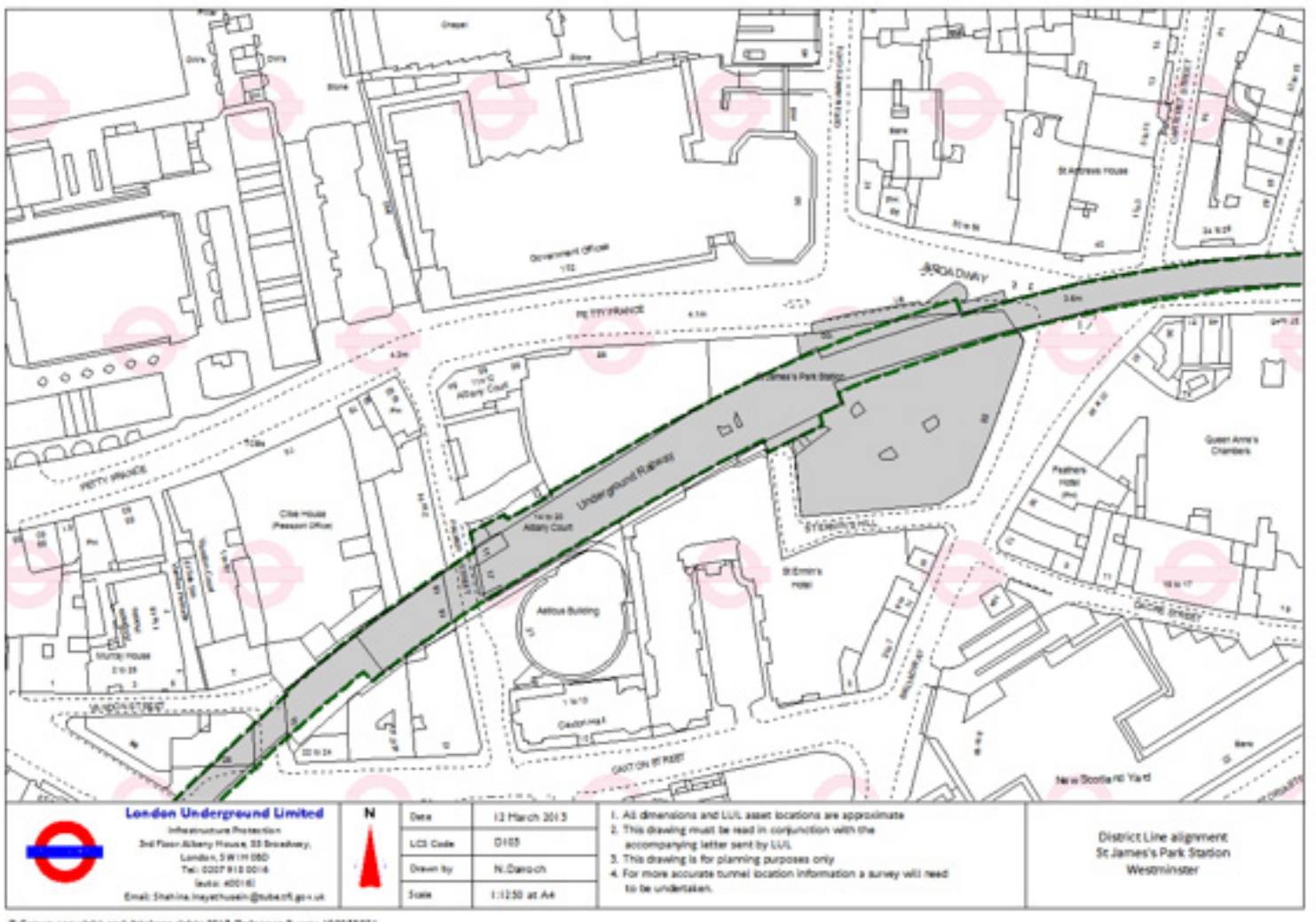

Figure 6: 1:1250 at A4 plan, showing St James's Park Station, with the District and Circle lines outlined dashed green and shaded gray, on 2013 OS mapping. The large area of gray to the east reflects the area developed as the head office of the Underground group in the 1920s, spanning the original station cutting. 


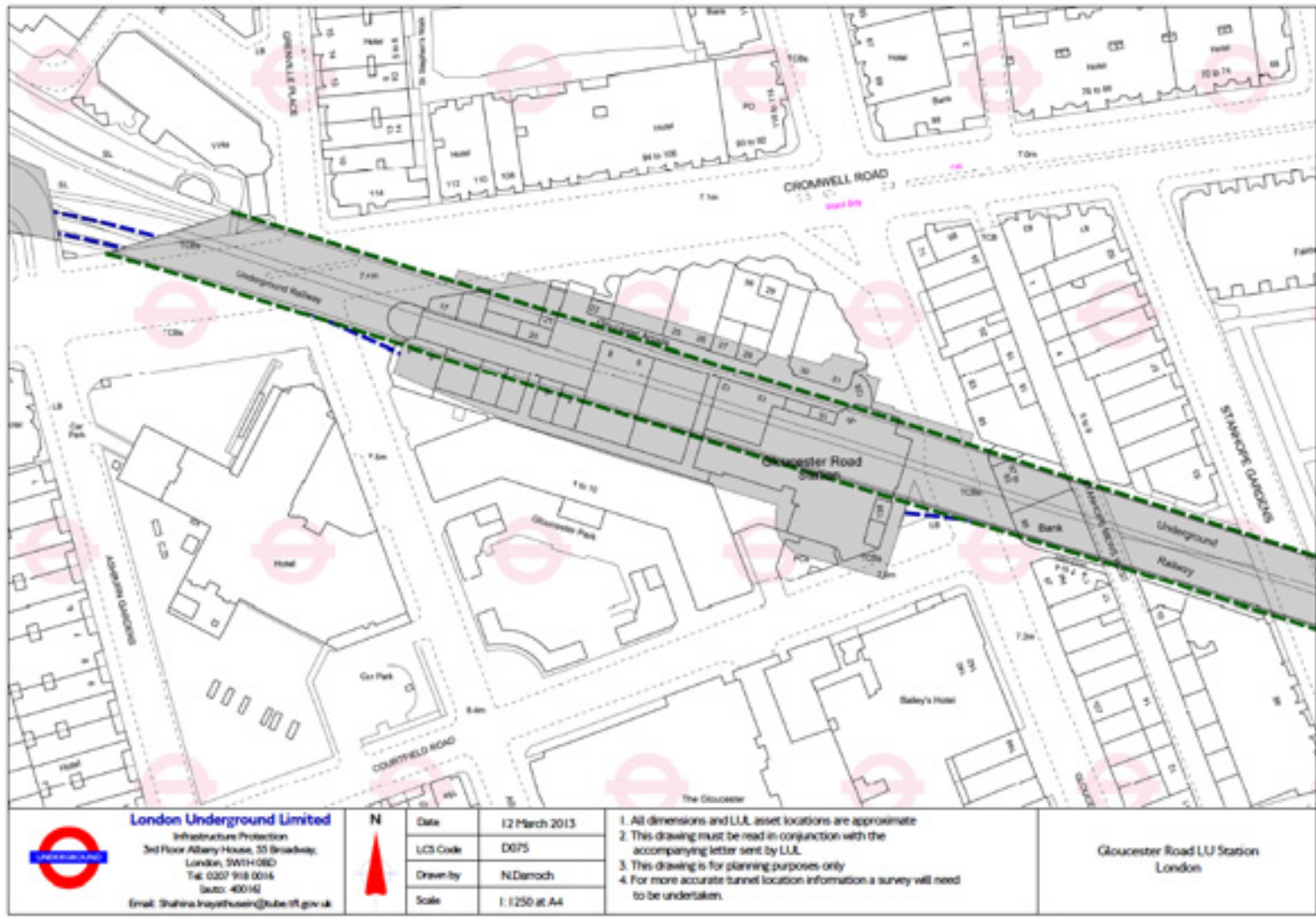

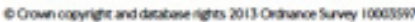

Figure 7: 1:1250 at A4 plan showing Gloucester Road Station, with the District and Circle lines outlined dashed green and shaded gray, on 2013 OS mapping. Before the rafting over of the station it was in open cutting.

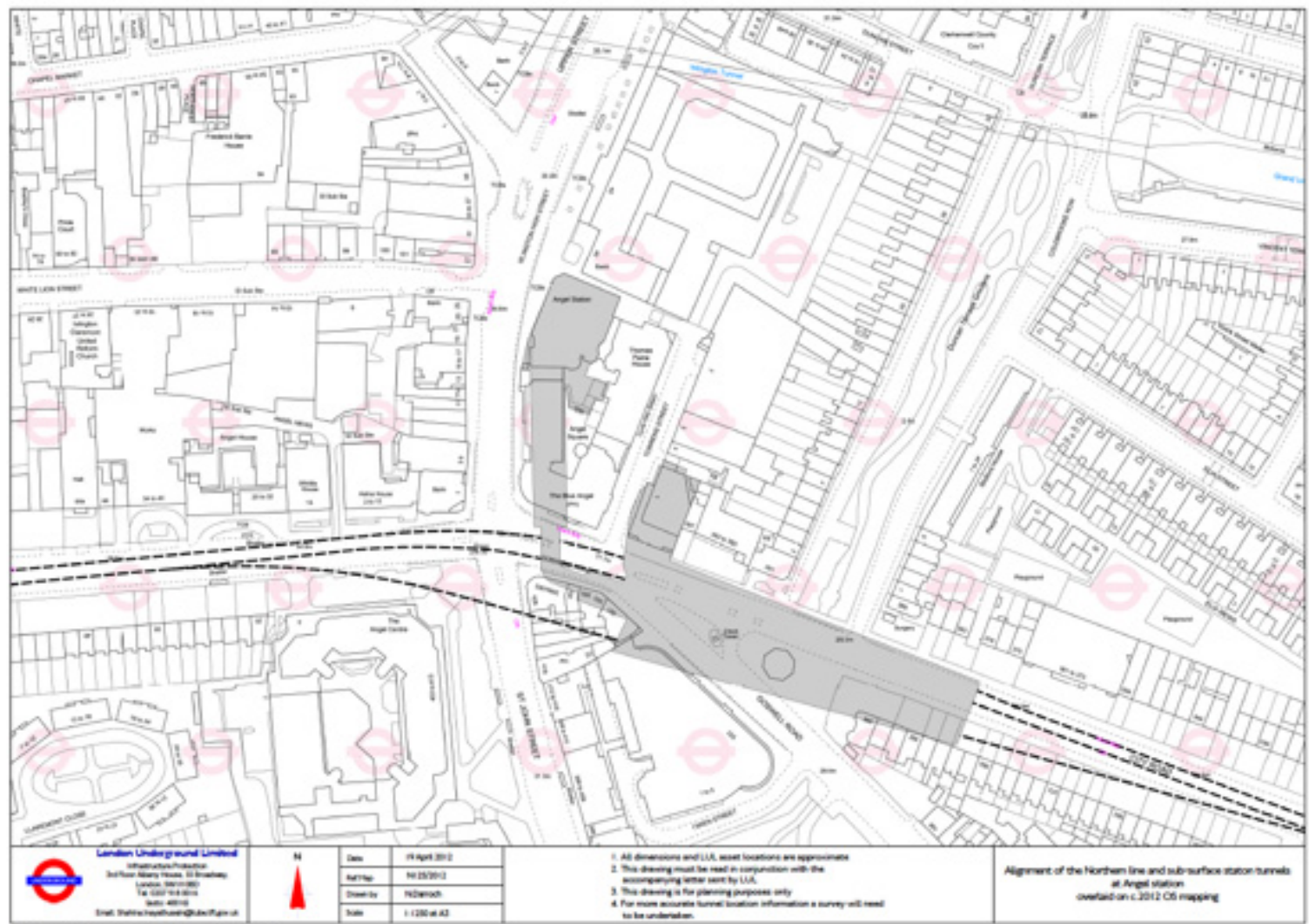

Figure 8: 1:1250 at A3 plan, showing Angel Northern Line Station on the Bank branch of the Northern line. The gray shaded area extending north, represents the alignment of the escalator shaft constructed in the 1980s to replace the original lifts. 


\subsection{Providing additional facilities}

Whereas the early tube stations used lifts to enable access to and from the trains, these began to restrict the flow of passengers, examples of this restriction still notable at stations such as Covent Garden station on the Piccadilly line, which regularly sees congestion and its use as an exit only, due to the use of lifts instead of escalators. With the need to rebuild stations from the 1920 s, to cater for greater traffic flows, escalators were introduced. To minimize their effect on adjoining properties, bearing in mind there was the issue of having to purchase an easement through the sub-soil, many escalator shafts were located under the public highway. At Oval, where escalators replaced lifts for example, the escalator shaft was purposefully driven under the road junction. At South Wimbledon on the Morden extension of the Northern line, opened in 1926, the escalator shaft and station tunnels are located under private property (fig. 9). This property, purchased by the railway company and sold on once the railway was complete, has covenants restricting what development can take place (Conveyance, dated 1 March 1933). This is because the large diameter of the station tunnels (about 7 metres), and the lack of space between them and the escalator shaft, has restricted development due to the minimal capacity for the foundations of any substantial development. The only way to develop the land, currently in use as a car park, would be to purchase and demolish adjoining property and to design a foundation solution that will transfer building loads away from the railway structures. However, such a proposal, if planning permission could be gained and property purchased, is likely to be prohibitive due to the cost.

\subsection{The presence of the railway under property}

The above example can also be used to highlight the issues of the presence of the railway under property especially within the central zone of the metropolis. As mentioned above, building design from the 1950s has seen more substantial buildings being erected, not only from ground level and above but also into the subsoil; the larger the development the greater the need for deeper foundations. Additionally there is the issue of size of buildings, especially in locations where there is a restriction on building height imposed by town planners. As such, developers are starting to build downwards with multiple basement levels to create more floor space and revenue from their development. For those properties that had a tube railway constructed under them, this becomes a problem for the engineers and designers of new development, as they must now take into account the presence of the railway, and potentially re-consider their proposals for the scale and type of development they had previously preferred.

\subsection{Ventilating the railway}

A tube railway consists of more than its tunnels and surface stations. They also need ventilation facilities, to ensure the fresh flow of air through the stations and tunnels. Whereas the early tube stations were designed to accommodate ventilation through their station buildings and vent shafts, it was soon found that this was unsatisfactory especially as user numbers rose, trains became more frequent and distances between stations increased. The solution was to provide additional ventilation between stations. At one location in Pimlico, on the 1970s built Victoria line extension from Victoria to Brixton, this resulted in the demolition of houses and the sinking of a ventilation shaft down to tunnel level and its continuation above ground level to approximately third floor level (fig. 10). The building constructed to contain the fans for forcing the air into and drawing it out of the tunnels, designed to blend into the row of houses within which it was located. However, this has resulted in a loss of land for purposes other than a railway that is a considerable depth below ground. If the properties either side were intended to be re-developed, the developers would need to take into account the presence of the shaft, next door.

\subsection{Incorporating railway assets within new development}

Though the tubes require facilities as considered above, they are not necessarily as disruptive to land use as the above examples may suggest. This is because, as with the sub-surface railways, it is possible to incorporate them within new property development. Many of the stations for the Central London Railway, for example, were designed to accommodate property development above the surface building as well as to allow ventilation (Joint Select Committee 1892 p.23.). This principle has been continued through to present-day station design, with stations such as Southwark on the Jubilee line extension, designed to be incorporated within future commercial development (Mitchell, 2003, p.160-163). With the rebuilding of earlier stations, facility was also included to accommodate the requirements of the railway, even where the station building was no longer required. When Piccadilly Circus Station was reconstructed to provide an under-highway ticket hall, in the 1920s the original station building, which incorporated a ticket office, staff accommodation, an electrical sub-station, and ventilation, did not fall out of use (fig. 11). Instead, it continued its use. This was even after the private redevelopment of the site for commercial use as shops and offices. The new development on the site, leased from London Underground, continues to provide facilities for ventilating the railway and power provision, today. Thus demonstrating that the railway 
can and is accommodated within commercial development and thus minimizes its effect on land use.

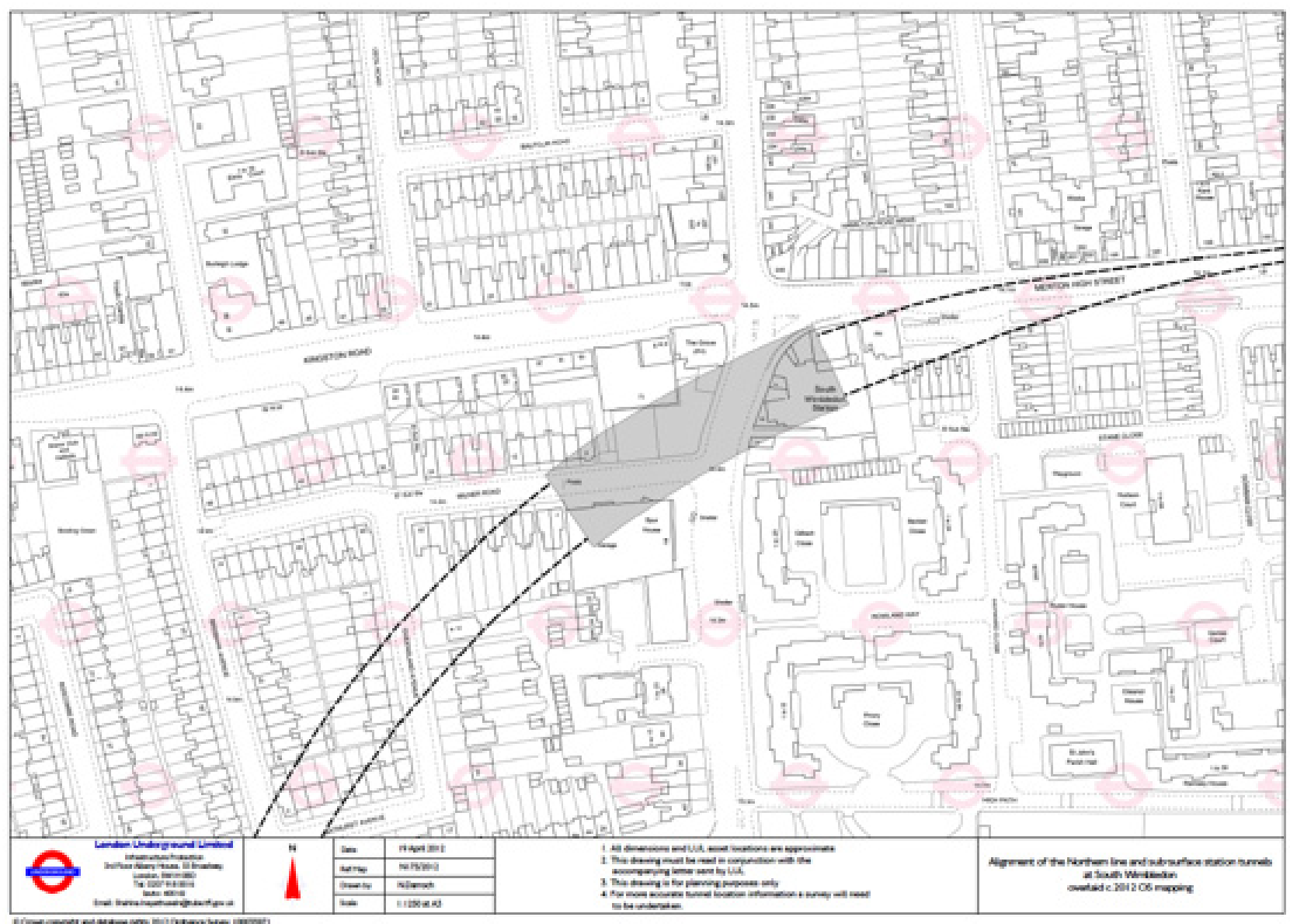

Figure 9: 1:1250 at A3 plan, showing South Wimbledon Station (shaded gray) on the Morden branch of the Northern line. The escalator shaft descends from the station building, on the east side of Merton Road, down between the station tunnels. The un-developable land is located in the center of the gray shaded area. 


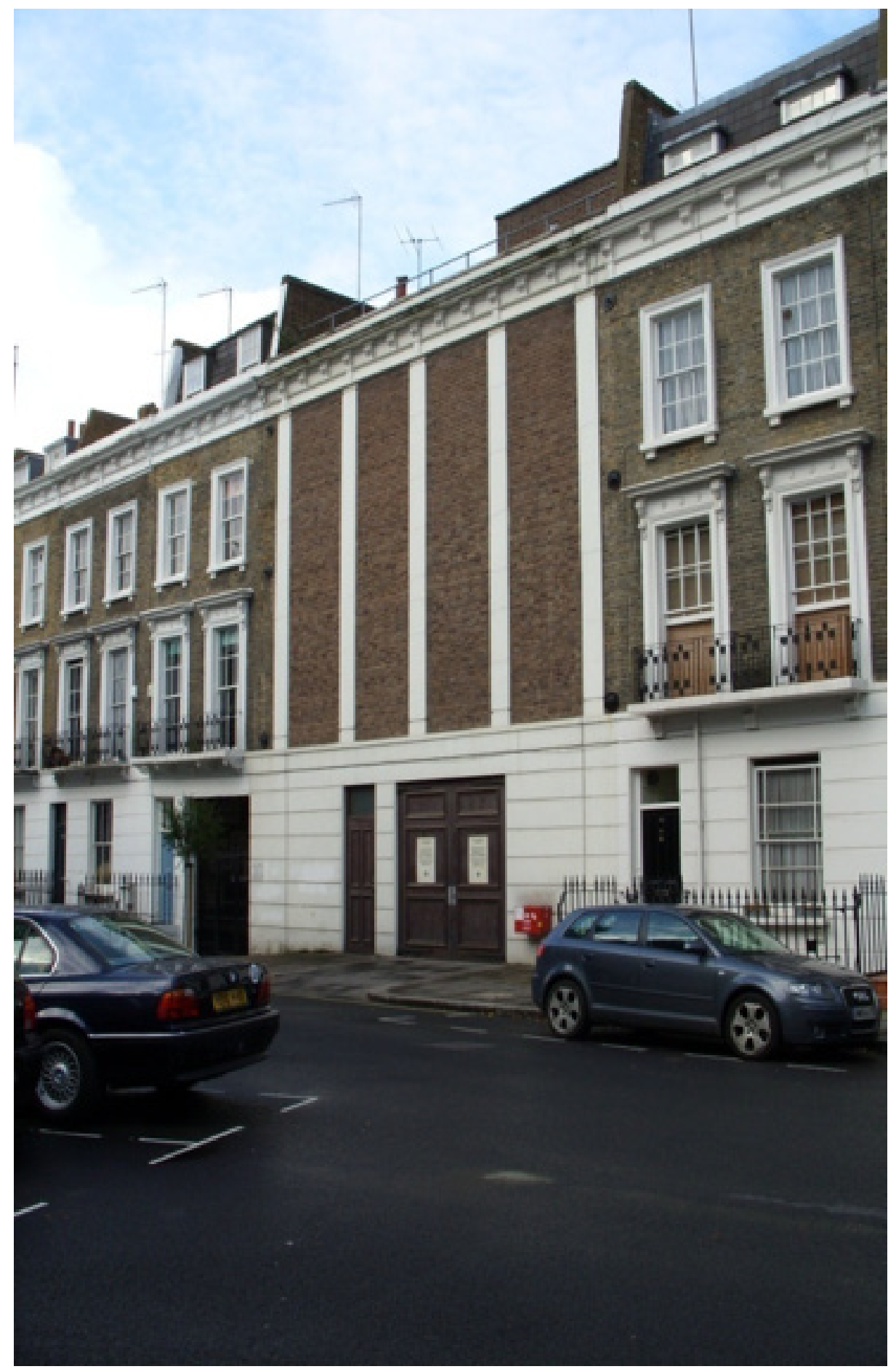

Figure 10: Photograph, showing the Head house building containing the ventilation shaft on the Brixton extension of the Victoria line. Note the adjoining private residential properties.

Author, 2012. Victoria line head house, Pimlico. 


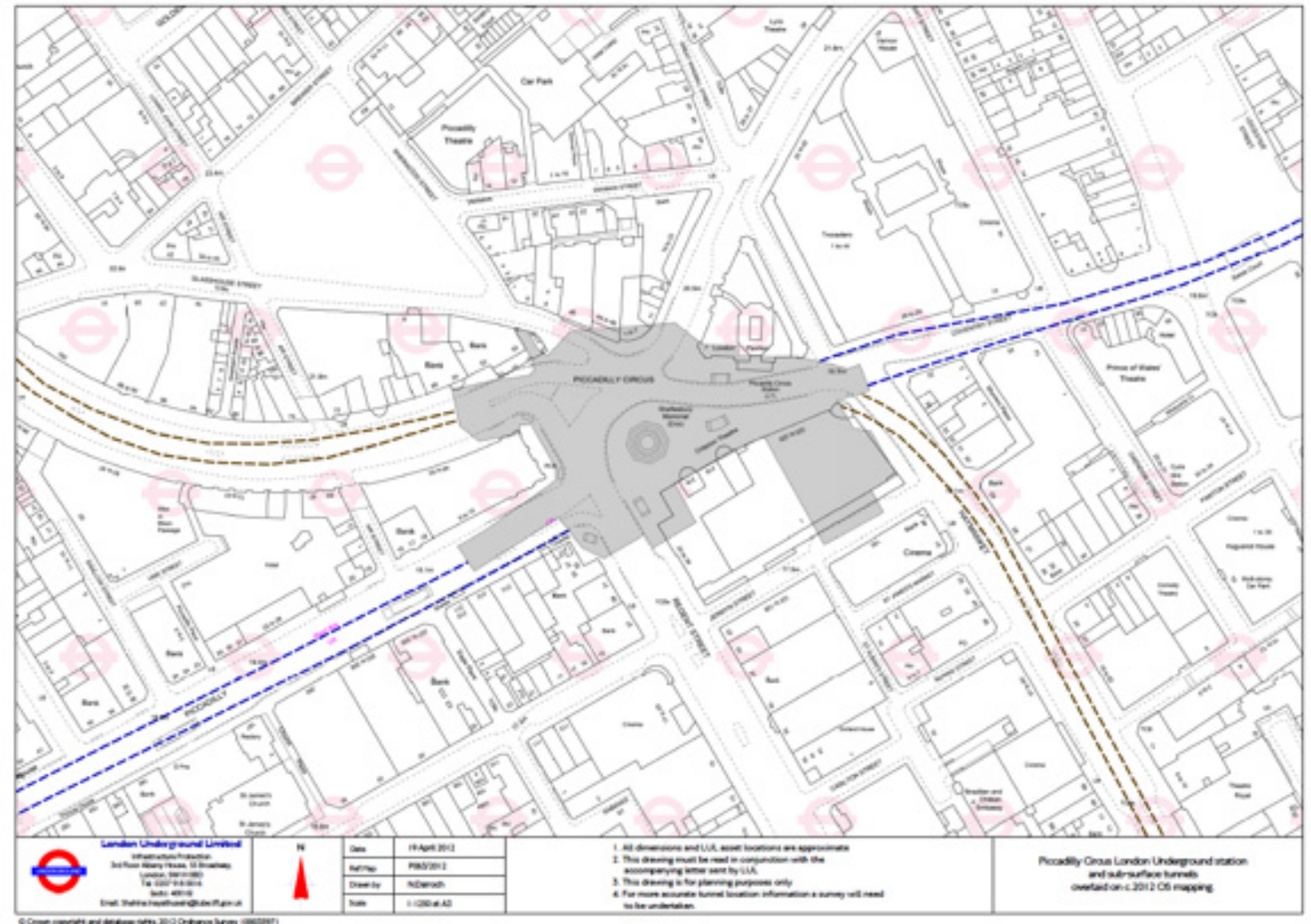

Figure 11: 1:1250 at A3 plan, showing Piccadilly Circus Station (shaded gray) which serves the Piccadilly and Bakerloo lines. The original station, replaced y the under highway ticket hall, and still utilised for operational purposes within an existing development is that portion of gray shading to the south of the circus.

\section{Conclusion}

The first section looked at the nature of the Metropolitan line, using the section between Great Portland Street and Farringdon. It considered how the railway is located under the public highway to minimize its incursion on private property, physically and legally, but pointing out that property must accommodate the presence of the railway. The limitations on shallow structures under property demonstrating that the presence of the tunnel can affect what kind of development can be undertaken. This was built upon by considering the presence of the railway in a cutting in an urban environment, and how redevelopment of neighboring property can be restricted by the presence of retaining walls and adjoining railway assets, as well as other private property.

The second section considered the presence of tube railways, and their essential related assets. It discussed the presence of the tunnels under the public highway to minimize the interface between the railway and property from a financial perspective, rather than an engineering one. Review was then made regarding related sub-soil structures and how the presence of these were again designed to minimize their affect on property, where possible. It showed that in some cases the avoidance of 'land blight' could not be avoided, and that the presence of the railway under property, while initially not a major concern can, today, affect what development is undertaken and how. Consideration then turned to the need for purpose-built buildings for the railway and how the assets within these can, on occasion, be incorporated in new commercial development.

This short paper has shown that though the railways are below ground in the central zone, they have a complicated relationship with property development, use of land and legal issues. Each affects the other in some way, whether it is seen or unseen. This relationship is much greater than appears to have been given credit by land-use planners, transport and land-use researchers, and urban historians previously. As such, it is suggested that those in these fields of research should give more consideration to the complexity of these interrelationships and undertake further and deeper research into the topics raised. 


\section{References}

British Transport Commission Act, 1955. (4 Eliz.2., c.xxx), London: HMSO.

Conveyance, dated 1 March 1933, between the City and South London Railway Company and the Cannon Brewery Company. TfL Muniments Archive: 1004181.

Darroch, N., 2013. London's Deep Tube Railways: Visibly Invisible. MA. University of York.

Dyos, H. J., 1955. Railways and housing in Victorian London. Journal of Transport History, 2, $1 \& 2$.

Dyos, H. J., 1957. Some social costs of railway building in London. Journal of Transport History, 2.

Parliamentary Session 1926 Folder 4, November 1925, Sheet 7, Metropolitan Railway Plans and Sections. LU Engineering Drawings Archive: 0000046556.

Reports of Committees, 1892. Report from the Joint Select Committee of the House of Lords and the House of Commons on the Electric and Cable Railways (Metropolis). [Online] House of Commons Parliamentary Papers, Online, House of Commons Papers. Available at http://parlipapers.chadwyck.co.uk/marketing/index.jsp [Accessed August 11, 2011].

Kellett, J.R., 1969. The Impact of Railways on Victorian Cities. London: Routledge \& Kegan Paul.

Kellett, J., 1993. The Victorian City: A reader in British urban history 1820-1914. London/New York: Longman.

Levinson, D., 2008. Density and Dispersion: the Co-Development of Land Use and Rail in London. Journal of Economic Geography, 8, p.55-77.

London Transport Act 1966. (c.xxxiii), London: HMSO.

Mitchell, R., 2003, The Jubilee Line Extension: From Concept to

Completion. London: ICE Publishing. 